\title{
Motivation as Myth or Reality in Modern Corporate World in Nepal: A Survey
}

\author{
Dr. Tej Narayan Prasad Nepali \\ Associate Professor, Nepal Commerce Campus
}

\begin{abstract}
Today's business organisation is not as before. Big machines, new technology, cut throat completion, changing interest of customers all these has changed the functioning of the corporate management. The modern corporate world want employees to be motivated at their job because most satisfied individuals work at the upper limit of their capacity for the good of the organization, while most dissatisfied individuals pursue ways to increase their level of satisfaction by working for their own gain. Every management tries to coordinate various factor of production in such a way that their contribution is maximum in achieving organizational goals. But, to improve the overall performance in a business it becomes essential to increase the efficiency of human beings. If a person does not have the capability or ability to do a work then he cannot increase his efficiency. On the other hand; even if a person has got the ability but is not properly motivated even then his performance will be low. Hence, the motivation should never be underrated.
\end{abstract}

The organizations of modern corporate world are basically concentrated on achievement of organizational target or goal. In this regard they mostly emphasized to change the traditional approaches of human resource management to motivated employees at work. The different policies regarding wage or salary, promotion, transfer, career development opportunity, job security, social security, bonus, performance appraisal, job evaluation, disciplinary action, etc. have been changed by the organizations of the modern corporate world in such a manner so that the employees could be self-motivated at work.

This research paper aims to find out the different factors influencing the level of motivation in modern corporate world and the required changes in the schemes or benefits, policies, etc. for improvement of the level of motivation to minimization of the migration of labour force. The will focus attention to find out that in modern corporate world the motivation is Myth or Reality. 
The modern corporate world want employees to be motivated at their job because most satisfied individuals work at the upper limit of their capacity for the good of the organization, while most dissatisfied individuals pursue ways to increase their level of satisfaction by working for their own gain. Every management tries to coordinate various factor of production in such a way that their contribution is maximum in achieving organizational goals. But, to improve the overall performance in a business it becomes essential to increase the efficiency of human beings. If a person does not have the capability or ability to do a work then he cannot increase his efficiency. On the other hand; even if a person has got the ability but is not properly motivated even then his performance will be low. Hence, the motivation should never be underrated. To reach high levels of performances an employee must want to do the job well (motivation), must be able to do the job effectively (ability) and must have the materials, resources, equipment and information to do the job (environment). A deficiency in any one of these areas hurts performance. A manager should thus strive to ensure that all three conditions are met.

Employees all over the world not only want job security but also want quality employment. They desire to be given ample opportunities for advancement, good working conditions, and fair treatment by managers, and autonomy on their work, challenging jobs and responsibility. Today's organizations focus on teamwork and cohesion among the group so as to create an inductive environment for work where employees are motivated to work and contribute to attaining the goals of the organization. The motivated employees become an asset to the organisation. Some importance of motivation are - High performance, Low Rate of Turnover and Absenteeism of Employee, Better Organizational Image, Better Industrial Relations, Acceptability to Change, Behaviour of the Employee Regarding Organizational Goal, Productive use of resources, etc. In modern corporate world, different organizations also adopt motivational techniques whether they may be in form of positive or negative efforts.

The organizations of modern corporate world are basically concentrated on achievement of organizational target or goal. In this regard they mostly emphasized to change the traditional approaches of human resource management to motivated employees at work. The different policies regarding wage or salary, promotion, transfer, career development opportunity, job security, social security, bonus, performance appraisal, job evaluation, disciplinary action, etc. have been changed by the organizations of the modern corporate world in such a manner so that the employees could be self-motivated at work.

\section{Objectives of Study:}

The Researcher had certain basic objectives for undertaking this research work i.e.

1. To find out the different factors influencing the level of motivation in modern corporate world. 
2. To find out the important problems related to motivation.

3. To analyze the main difference in employment conditions related to motivation;

4. To find out the needs of employees belonging to modern corporate world due to which they feel some extent dissatisfy;

5. To illustrate tentative contribution of modern corporate world regarding improvement of the level of motivation;

6. To find out the possibility of change in employment conditions to development the level of motivation;

7. To find out the required changes in the schemes or benefits, policies, etc. for improvement of the level of motivation.

8. To acknowledge that how far the utilization of labour forces and minimization of the migration of labour force from any organization will be possible with the help of the study.

9. To find out that in modern corporate world the motivation is Myth or Reality;

These were the basic areas which researcher aims to examine in this research.

Besides these areas, some other allied areas were also be taken into consideration.

\section{Methodology:}

The Researcher conducted a survey on the subject matter that - "Motivation is a Myth or Reality in Modern Corporate World" in the country. The researcher visited different organisations like Standard Chartered Bank, Nepal Telecommunication, Nepal Bottlers, Alkem Pharmaceuticals, Tata Moters, Sipradi Trading, Nepal Electricity Authority, etc. Total 150 persons were interviewed during the survey through formulated schedule. The all persons were employed in different organizations of corporate world and holding different job positions. There is one specific characteristic of the all respondents that all were not only literate but also were having the degree of technical or management.

\section{Analysis and Interpretation:}

The responses given by the employees belonging to modern corporate world about the subject matter of satisfaction with salary offered in commensurate with qualifications and experience has been analyzed below:

Table -1

Satisfaction with Salary

\begin{tabular}{|c|l|c|c|}
\hline S.N. & \multicolumn{1}{|c|}{ Satisfaction with salary } & No. & $\%$ \\
\hline 1 & Highly satisfied & 40 & 26.67 \\
\hline 2 & Satisfied. & 105 & 70.00 \\
\hline 3 & So-so & 5 & 3.33 \\
\hline 4 & Dissatisfied & Nil & Nil \\
\hline 5. & Highly dissatisfied & Nil & Nil \\
\hline \multicolumn{2}{l|}{ Total } & 150 & 100 \\
\hline
\end{tabular}

It means the organizations of modern corporate world pay adequate amount of 
salary as per the qualification and experience of the employees.

The purpose of any social security measure is to give individuals and families the confidence that their level of living and quality of life will not erode by social or economic eventuality; provide medical care and income security against the consequences of defined contingencies; facilitate the victims physical and vocational rehabilitation; prevent or reduce ill health and accidents in the occupations; protect against unemployment by maintenance and promotion of job creation and provide benefit for the maintenance of any children. The opinion of respondents regarding social security has been analyzed below:

$$
\text { Table }-2
$$

Types of Social Security Benefit

\begin{tabular}{|c|l|c|c|}
\hline S.N. & Types of social security benefit & No. & $\%$ \\
\hline 1 & Contributory Provident Fund Scheme & 150 & 100 \\
\hline 2 & New Pension Scheme & 76 & 50.67 \\
\hline 3 & Gratuity & 150 & 100 \\
\hline 4 & Group Insurance Scheme & 150 & 100 \\
\hline 5 & Sabbatical Leave & 18 & 12.00 \\
\hline 6 & Compensatory Leave & 135 & 90.00 \\
\hline
\end{tabular}

Housing facility is an important welfare facility and if an employer does not provide housing facility then he pays house rent allowance to their employees. The opinion of respondents regarding housing facility has been analyzed below:

$$
\text { Table }-3
$$

Satisfaction due to Housing Facility

\begin{tabular}{|c|l|c|c|}
\hline S.N. & \multicolumn{1}{|c|}{ Satisfaction due to Housing Facility } & No. & $\%$ \\
\hline 1 & Satisfactory & 13 & 8.67 \\
\hline 2 & So-so & 7 & 4.66 \\
\hline 3 & Not satisfactory & Nil & Nil \\
\hline 4 & Not applicable & 130 & 86.67 \\
\hline \multicolumn{2}{|l|}{ Total } & 150 & 100 \\
\hline
\end{tabular}

Medical facility is an important welfare measure for the employees to restore their working efficiency for work in case of sickness, maternity and employment injury. The opinion of respondents regarding medical facility has been analyzed below:

Table -4

\section{Satisfaction due to Medical facility}

\begin{tabular}{|c|l|c|c|}
\hline S.N. & \multicolumn{1}{|c|}{ Satisfaction due to Medical facility } & No. & $\%$ \\
\hline 1 & Satisfactory & 20 & 13.33 \\
\hline 2 & So-so & Nil & Nil \\
\hline 3 & Not satisfactory & Nil & Nil \\
\hline 4 & Not applicable & 130 & 86.67 \\
\hline \multicolumn{2}{|l}{ Total } & 150 & 100 \\
\hline
\end{tabular}


A canteen is a facility which serves food in a cafeteria-style setting. The word refers generally to refreshments. Canteen provision is neither philanthropy nor charity. It is a method of creating more satisfactory working and living conditions for men and women employed in an industry. The opinion of respondents regarding canteen facility has been analyzed below:

$$
\text { Table }-5
$$

Satisfaction due to Canteen facility

\begin{tabular}{|c|l|c|c|}
\hline S.N. & \multicolumn{1}{|c|}{ Satisfaction due to Canteen facility } & No. & $\%$ \\
\hline 1 & Satisfactory & 127 & 84,67 \\
\hline 2 & So-so & 23 & 15.33 \\
\hline 3 & Not satisfactory & Nil & Nil \\
\hline 4 & Not applicable & Nil & Nil \\
\hline \multicolumn{2}{l|}{ Total } & 150 & 100 \\
\hline
\end{tabular}

Generally employees have to suffer the worst due to misconduct or eve teasing by co-passengers. Sometimes they have to wait for hours on the bus stop to board a bus. The organizations of modern corporate world provide the transport facility, Pick and drop facility as well as transport facility in the form of travelling allowance. The opinion of respondents regarding transport facility has been analyzed below:

$$
\text { Table - } 6
$$

Satisfaction due to Transport facility

\begin{tabular}{|c|l|c|c|}
\hline S.N. & \multicolumn{1}{|c|}{ Satisfaction due to Transport facility } & No. & $\%$ \\
\hline 1 & Satisfactory & 150 & 100 \\
\hline 2 & So-so & Nil & Nil \\
\hline 3 & Not satisfactory & Nil & Nil \\
\hline 4 & Not applicable & Nil & Nil \\
\hline \multicolumn{2}{l}{ Total } & 150 & 100 \\
\hline
\end{tabular}

The period between arrival at work and departure from the work by any employed person is generally considered as period of work. The longer hours of work in the organisation dissatisfy the mental status of the employees. The opinion of respondents regarding working hours has been analyzed below:

Table- 7

Satisfaction due to Working Hours

\begin{tabular}{|c|l|c|c|}
\hline S.N. & Satisfaction due to Working Hours & No. & $\%$ \\
\hline 1 & Yes & 150 & 100 \\
\hline 2 & No & Nil & Nil \\
\hline \multicolumn{2}{|c|}{ Total } & 150 & 100 \\
\hline
\end{tabular}

The opinion of respondents regarding Transparency in Assessment Report (Annual Confidential Report) has been analyzed below: 
Table- 8

Transparency in Assessment Report (Annual Confidential Report)

\begin{tabular}{|c|l|l|l|}
\hline S.N. & Transparency in Assessment Report (Annual Confidential Report) & No. & \multicolumn{1}{|c|}{$\%$} \\
\hline 1 & Yes & 139 & 92.67 \\
\hline 2 & No & Nil & Nil \\
\hline 3 & Sometime adopted & Nil & Nil \\
\hline 4 & Mostly adopted & 11 & 7.33 \\
\hline \multicolumn{2}{|l|}{ Total } & 150 & 100 \\
\hline
\end{tabular}

The impact of career advancement scheme can be seen through the productivity indicator, job attitude, job commitment and reduction in attrition rate. The opinion of respondents regarding existence of Career Advancement Scheme has been analyzed below:

Table- 9

Existence of Career Advancement Scheme

\begin{tabular}{|c|l|c|c|}
\hline S.N. & Satisfaction due to Existence of Career Advancement Scheme & No. & $\%$ \\
\hline 1 & Highly satisfied & 70 & 46.67 \\
\hline 2 & Satisfied & 30 & 20.00 \\
\hline 3 & Partially satisfied & 50 & 33.33 \\
\hline 4 & Not satisfied & Nil & Nil \\
\hline \multicolumn{2}{l|}{ Total } & 150 & 100 \\
\hline
\end{tabular}

Nature of service also affects the performance as well as job satisfaction of employees. The opinion of respondents regarding nature of service has been analyzed below:

Table- 10

Nature of service

\begin{tabular}{|c|l|c|c|}
\hline S.N. & \multicolumn{1}{|c|}{ Nature of service } & No. & $\%$ \\
\hline 1 & Permanent & 150 & 100 \\
\hline 2 & Temporary & Nil & Nil \\
\hline 3 & Contractual & Nil & Nil \\
\hline \multicolumn{2}{|l|}{ Total } & 150 & 100 \\
\hline
\end{tabular}

Leave and holiday are considered as leave with wages because in case of leave as well as holiday the employees avail leave and also receive wage or salary for those days. The opinion of respondents regarding leave with wages has been analyzed below:

Table- 11

Types of Leaves with Wages

\begin{tabular}{|c|l|c|c|}
\hline S.N. & Types of Leaves with Wages & No. & $\%$ \\
\hline 1 & Casual leave & 150 & 100 \\
\hline
\end{tabular}




\begin{tabular}{|c|l|c|c|}
\hline S.N. & \multicolumn{1}{|c|}{ Types of Leaves with Wages } & No. & $\%$ \\
\hline 2 & Medical leave & 150 & 100 \\
\hline 3 & Maternity leave & 44 & 29.33 \\
\hline 4 & Paternity leave & 24 & 16.00 \\
\hline 5 & Earn leave & 150 & 100 \\
\hline 6 & Compensatory leave & 135 & 90 \\
\hline 7 & Educational leave & 18 & 12.00 \\
\hline
\end{tabular}

Performance evaluations may be used as a starting point for discussions of training, development and improvement. To determine the level of performance of all employees the organizations of modern corporate world have been introduced different methods of appraisal. There is a general consensus among performance appraisal researchers and practitioners that assessment of appraisal reactions is important. The opinion of respondents regarding satisfaction due to performance appraisal system in the organization has been analyzed below:

Table- 12

Satisfaction of Employees due to Performance appraisal system

\begin{tabular}{|c|l|c|c|}
\hline S.N. & Satisfaction of Employees due to Performance appraisal system & No. & $\%$ \\
\hline 1 & Highly satisfied & 119 & 79.34 \\
\hline 2 & Satisfied & 17 & 11.33 \\
\hline 3 & To some extent satisfied & 14 & 9.33 \\
\hline 4 & Not satisfied & Nil & Nil \\
\hline \multicolumn{2}{|l}{ Total } & 150 & 100 \\
\hline
\end{tabular}

Employee attrition refers to the loss of employees through a number of circumstances, such as resignation, retirement, etc. There are two factors namely pull factor and push factor related to attrition of employees because these factors motivate employees to leave the job of an organization and to join the other organization. The opinion of respondents regarding the reasons of attrition in the organizations has been analyzed below:

Table- 13

\section{Reasons regarding Attrition}

\begin{tabular}{|c|l|c|c|}
\hline S.N. & \multicolumn{1}{|c|}{ Reasons regarding Attrition } & No. & $\%$ \\
\hline 1 & Better opportunity & 118 & 78.67 \\
\hline 2 & High amount of perks & 28 & 18.67 \\
\hline 3 & Work load & Nil & Nil \\
\hline 4 & Pressure of the organization regarding better performance & Nil & Nil \\
\hline 5 & Leadership approach & 4 & 2.66 \\
\hline \multicolumn{2}{|l|}{ Total } & 150 & 100 \\
\hline
\end{tabular}

The over sensitive person feels the pain in an exaggerated way and so has 
problems tolerating life difficulties. There are different reasons of growing tendency or nature of insensitiveness among persons mostly belonging in urban areas likeexpensive living cost, lack of blood relations neighbours, fear of fraud, possibility of undue sexual harassment, demand of money or commodity on credit, busy daily routine life, fear related to undue advantage by others, possibility of expenses on other persons, etc. The opinion of respondents about the reasons regarding insensitivity of employees in the organizations of modern corporate world has been analyzed below:

Table- 14

Reasons regarding the insensitivity

\begin{tabular}{|c|l|c|c|}
\hline S.N. & \multicolumn{1}{|c|}{ Reasons regarding Insensitiveness } & No. & $\%$ \\
\hline 1 & Poor level of trust & 88 & 58.67 \\
\hline 2 & Fear related to undue advantage & 6 & 4.00 \\
\hline 3 & Consideration of own goal or performance & 56 & 37.33 \\
\hline 4. & Any other reason & Nil & Nil \\
\hline Total & 150 & 100 \\
\hline
\end{tabular}

The data indicates that poor level of trust on other employees and consideration of own goal or performance in respect to other employees of the organization, the employees are becoming more insensitive in modern corporate world. Due to insensitiveness of employees the sympathy of a person dies and social interaction minimizes. It also changes the emotional affection of a person at working place.

\section{Main Findings}

Some important findings of the study are as follows:

1. Total $96.67 \%$ of the respondents were either highly satisfied or satisfied with salary offered in commensurate with qualifications and experience. It means the organizations of modern corporate world pay adequate amount of salary as per the qualification and experience of the employees.

2. $\quad 100 \%$ respondents opined that Contributory Provident Fund, Gratuity and Group Insurance are important social security measures for the employees employed in different organizations of the modern corporate world.

3. Maximum organizations of modern corporate world do not provide housing facility to their employees because the house rent in urban areas is higher in respect to the payable amount of house rent allowance so they prefer to pay house rent allowance to the employees. 4. Maximum corporate world do not provide medical facility to their employees and prefer to pay medical allowance to the employees. Similarly the private undertakings do not want to invest a huge amount in construction of hospital in urban areas for their employees. However the public sector undertakings prefer to construct hospital for their employees. The medical facility is also a motivational effort which provides security in case of ill health to employees.

5. All organizations of modern corporate world provide the canteen facility to their employees. However the size, supplied facilities in canteen may differ. 
Such facility reduces the misuse of time, better health of the employees and also refreshes the employees at work to provide tea or coffee during work. It enhances output of the employees and motivates also to continue the service till superannuation.

6. All organizations of modern corporate world are providing transport facility to their employees to complete the different work activities in satisfactory manner. It is also an important motivational effort for the employees.

7. Total respondents were satisfied due to working hours of the organizations. It is also a reason of motivation due to which the employees perform their assigned work in better manner and with dedication in private sector undertakings also. However the employees of marketing division devote more time to visit different places.

8. All respondents accepted Transparency in Assessment Report (Annual Confidential Report) in the organizations. It may be an important reason of motivation of employees because in such situation the employees feel no discrimination so far as the performance is concerned. Similarly in case of poor performance the organizations take necessary action also. It means the organizations follow the principle of "Hot Stove Rule" which is based on the concept of 'no discrimination and quick action'.

9. All respondents were either satisfied or partial satisfied due to career advancement scheme of the organizations. They opined that the Career Advancement Schemes in the organizations are performance based. The best performers are more benefitted in respect to the average performers. So the employees are found satisfied to consider their performance and feel no discrimination in the organizations and hope that they will be benefitted or rewarded in case of better performance as per the organizational policies. It means the policy of seniority has been totally replaced by merit or performance. It may be the reason of motivation of the employees in modern corporate world.

10. All respondents were employed on permanent basis and no any respondent was either contractual or temporary. It means the organisations of modern corporate world provide employment as permanent employees and the survival depends on performance. It may be the reason of motivation due to which the employees retain in the organizations for longer period and try to render meritorious service in the organizations.

11. The organizations of modern corporate world also provide different types of leave with wages to their employees in case of sickness, maternity and even to participate in social ceremony as well as festivals. But such types of leave or holidays are not an additional effort of the organizations of modern corporate world because regarding these leaves or holidays the statutory provisions are implemented by the government in the country. No any special leave is provided by the organizations of modern corporate world to motivate their employees.

12. The organizations of modern corporate world also adopt the system of performance appraisal to evaluate or justify the level of performance and work done of the employees whether they are suitable for the job at which level. With the help of 
performance appraisal the organizations also formulate some specific strategies regarding promotion, enhancement of salary or package of remuneration, termination, training or development, transfer, etc. of the employees. The data indicates that most of the respondents were either highly satisfied or satisfied due to performance appraisal system of the organisations which also motivate employees at work and do best as per their efficiency.

13. The organizations of modern corporate world provide better job opportunity and high amount of perks due to which generally attrition is found. Both of these are not motivational force to retain as well as motivate the employees of the organization but both will be considered as pull factor which attract efficient and qualified persons to leave the present organizations and join the new organizations.

14. The poor level of trust on other employees and consideration of own goal or performance in respect to other employees of the organization, the employees are becoming more insensitive in modern corporate world. Due to insensitiveness of employees the sympathy of a person dies and social interaction minimizes. It also changes the emotional affection of a person at working place.

\section{Suggestions:}

Some important suggestions may be concluded on the basis of the study, which are as follows:

1. There is no job security to the employees working in different organizations of modern corporate work and they are found always feared due to termination of employment in case of non-achievement of the target or goal and work under stress. The job security to such employees should be incorporated under legal provisions as motivational effort.

2. There are different situational factors which adversely affect the output or performance of the employees but the organizations of modern corporate world do not consider the situational impacts and only consider the present or existing output or work-done of the employees. The adverse impact of the situations should be considered by the organization at the time of performance appraisal so that the employees could motivate.

3. The number of employed persons in corporate world belonging to urban areas was higher in respect to other areas because due to unemployment as well as considering the life of town they prefer to join the employment of corporate world because the entire offices are situated in urban areas. So without any motivational effort they are motivated at work for their livelihood. So it is myth that the modern corporate world adopts motivational efforts for their employees.

4. The organizations of modern corporate world are situated in urban areas. The location of organization also motivate the persons to join the employment or job of modern corporate world because the persons could avail different types of facilities like- electricity, better educational facility to children, transportation facility, commodities on lower price in respect to rural areas, etc. for themselves as well as for families. Such factors also retain the employees in the organizations 
of modern corporate world.

5. The domiciliary of maximum respondents was North India and then after the Eastern India. The persons belonging to North India like employment anywhere for earning because they have no motivation for self-employment. Basically employment in reputed organizations and in public sector is considered as status symbol and such jobs have social recognition. Similarly limited opportunity of employment, poor per capita income in more Northern States and huge population, they are also motivated to join job in corporate world in any capacity. So, it is myth that the modern corporate world imposes pull factor of motivation.

6. There is more demand of technical degree in modern corporate world in respect to the general academic degree. The number of jobs in the country is limited in respect to the number of technical degree holder job seekers and a lot of job seekers are included every year in total labour force. A lot of technical or professional institutions are supplying technical human resources. In such situation they are compelled to render dedicated service to continue in service without any additional effort of motivation.

7. The employees of modern corporate world try to develop their career and monetary benefit to give meritorious service in any organization but in case of better opportunity they leave the job. Similarly the better job opportunity to average employees is limited and the employees having excellent performance opportunity where they join first. The situation of unemployment also retains the employees and in case of better adjustment as well as work culture the employees try to serve the organizations for longer period also.

8. The young persons have more employment opportunity in private sector in respect to the public sector. Presently the age group of maximum employees of corporate world can be found between 31- 40 years. However the persons prefer to join public sector considering the job security in case of job opportunity. But if they do not seek employment in public sector then they join private sector and try to render meritorious service for longer period.

9. The organizations of modern corporate world pay adequate amount of salary as per the qualification and experience of the employees. However the organizations of modern corporate world also adopt the principle of wage differential on the basis of performance or achievement of target and such principle is adopted by private sector undertakings in frequent manner. Considering the equity in payment or enhance the amount of payment they are motivated to do better in the organization.

10. Contributory Provident Fund, Gratuity and Group Insurance are important social security measures for the employees employed in different organizations of the modern corporate world. But these all benefits are given to the employees under legal provisions made by the Central Government. No any non-statutory scheme of social security has been introduced by the organizations of modern corporate world to motivate employees at work.

11. Maximum organizations of modern corporate world do not provide housing facility to their employees because the house rent in urban areas is higher in 
respect to the payable amount of house rent allowance so they prefer to pay house rent allowance to the employees. Similarly the private undertakings do not want to invest a huge amount in construction of house in urban areas for their employees. However the public sector undertakings prefer to construct houses for their employees. The housing facility is also a motivational effort which provides security in case of ill health to employees.

12. Maximum organizations of modern corporate world do not provide medical facility to their employees and prefer to pay medical allowance to the employees. Similarly the private undertakings do not want to invest a huge amount in construction of hospital in urban areas for their employees. However the public sector undertakings prefer to construct hospital for their employees. The medical facility is also a motivational effort which provides security in case of ill health to employees.

13. All organizations of modern corporate world provide the canteen facility to their employees. However the size, supplied facilities in canteen may differ. Such facility reduces the misuse of time, better health of the employees and also refreshes the employees at work to provide tea or coffee during work. It enhances output of the employees and motivates also to continue the service till superannuation.

14. Some organizations of modern corporate world were providing transport facility separately to some employees but in case of some organizations it was found that the organization provide pick and drop facility of transport due to problem of parking space. But the employees of marketing division were availing travelling allowance against the transport facility. All organizations of modern corporate world are providing transport facility to their employees to complete the different work activities in satisfactory manner. It is not an additional effort for motivation of the employees.

15. Except marketing division other employees were satisfied due to working hours of the organizations. It is also a reason of motivation due to which the employees perform their assigned work in better manner. However the employees of marketing division devote more time to visit different places.

16. There is legal provision to maintain fire ceaser in all organisations to protect the life of employees in case of fire. As per provision the organizations of modern corporate world are also compelled to maintain proper and adequate arrangement of fire \& safety measures in the organizations. It is not additional effort of motivation.

17. All employees were satisfied due to Transparency in Assessment Report (Annual Confidential Report) or performance appraisal system in the organizations. It may be an important reason of motivation of employees because in such situation the employees feel no discrimination so far as the performance is concerned. Similarly in case of poor performance the organizations take necessary action also. It means the organizations follow the principle of "Hot Stove Rule" which is based on the concept of 'no discrimination and quick action'.

18. Maximum respondents refused about the biasness in performance appraisal 
system of the organization and they had faith in the performance appraisal system of the organizations. It may be reason due to which maximum employees of the modern corporate world are self-motivated about their jobs and no specific effort is required for the organizations to motivate their employees.

19. In the different organizations of modern corporate world the performance appraisal is done after one to one discussion and directly linked with achievement of goal or target. So the employees become able to discuss their problems related to performance and satisfy to acknowledgement their progress or output.

20. The employees were either satisfied or partial satisfied due to career advancement scheme of the organizations. The Career Advancement Schemes in the organizations were performance based. The best performers were more benefitted in respect to the average performers. So the employees were found satisfied and self-motivated in the organizations of modern corporate world.

21. The employees were employed on permanent basis and no any employee was either contractual or temporary. It may be the reason of motivation due to which the employees retain in the organizations for longer period and try to render meritorious service in the organizations.

22. The organizations of modern corporate world also provide different types of leave with wages to their employees in case of sickness, maternity and even to participate in ceremony as well as festivals. But such types of leave or holidays are not an additional effort of the organizations of modern corporate world because regarding these leaves or holidays the statutory provisions are implemented by the government in the country. No any special leave is provided by the organizations of modern corporate world to motivate their employees.

23. The organizations of modern corporate world also adopt the system of performance appraisal to evaluate or justify the level of performance and work done of the employees whether they are suitable for the job at which level. With the help of performance appraisal the organizations also formulate some specific strategies regarding promotion, enhancement of salary or package of remuneration, termination, training or development, transfer, etc. of the employees. The employees become self-motivated to do better in favour of the organization. It is myth that the organizations of modern corporate world have been introduced any scheme to motivate employees at work.

24. The organizations of modern corporate world were more concentrate on achievement of goal or target of the organizations. Similarly the continuance of service as well as all other facilities was also linked with level of performance. So, the employees were self motivated towards the achievement of goal or target of the organizations.

25. The average rate of attrition in different organizations of modern corporate world was $10 \%$ which can be considered as normal attrition rate in present competitive era in which the organizations try to attract efficient and experienced employees from other organization.

26. It may be concluded that the organizations of modern corporate world provide better job opportunity and high amount of perks due to which generally attrition 
is found. Both of these are not motivational force to retain as well as motivate the employees of the organization but both will be considered as pull factor which attract efficient and qualified persons to leave the present organizations and join the new organizations.

27. The insensitiveness among employees belonging to different organizations in modern corporate world is gradually increasing and social sphere of the persons is downsizing. The employees are considering own and family interest only and ignore the interests of other persons either belonging to working society or residential society. It may the reason due to which the old-aged peoples are suffering from a lot of problems because even their sons or daughters are insensitive about them.

28. The poor level of trust on other employees and consideration of own goal or performance in respect to other employees of the organization, the employees are becoming more insensitive in modern corporate world. Due to insensitiveness of employees the sympathy of a person dies and social interaction minimizes. It also changes the emotional affection of a person at working place.

29. A distinction is sometimes made between market entrepreneurs and political entrepreneurs. Market entrepreneurs create wealth by selling goods and services to consumers at a profit. Political entrepreneurs, by contrast, enrich themselves by securing preferential treatment from the government. Most of the era's leading industrialists fell somewhere and creating real value in the market, but also seeking government favours whenever possible.

The study shows that in different organizations of modern corporate world the employers have not introduced any policy regarding to motivate employees at work. They have formulated policies regarding improve self-motivation of the employees at work considering the continuance of the job.

\section{Conclusion:}

The motivation of employees at work have been analyzes and interpreted by a group of scholars. The opinions of scholars about the motivation of employees are found different in nature. Different subject matters have been considered as motivational efforts of the employees. The perceptions as well as findings of the scholars are devoted to different aspects of the employment conditions and opinions, needs, socio-economic conditions, attitudes, etc. of employees.

The organizations of modern corporate world are basically concentrated on achievement of organizational target or goal. In this regard they mostly emphasized to change the traditional approaches of human resource management to motivated employees at work. The different policies regarding wage or salary, promotion, transfer, career development opportunity, job security, social security, bonus, performance appraisal, job evaluation, disciplinary action, etc. have been changed by the organizations of the modern corporate world in such a manner so that the employees could be self-motivated at work. 


\section{References}

Academy of Management Journal

Academic Leadership Journal

American Journal of Community Psychology

Harvard Business Review

Hospitality Education and Research Journal

International Migration Review

International Journal for the Scholarship of Teaching and Learning

J. Wood \& Others (2004). Organisational Behaviour- A Global Perspective, 3rd Edition, John Wiley

\& Sons, Milton

Jeffry, P. F. (1998). The Human Equation, Boston: Harvard Business School Press

Runyan, W.M. (1982). Life histories and psychobiography: Explorations in theory and method, New York: Oxford University Press.

Srivastava, R.M. Management Policy and Strategic Management: Concepts, Skills and Practices, Himalaya Publishing House.

Srinivas R. K. H.R.M in Practice, PHI

Vroom, V. (1964). Work and motivation. New York, NY: Wiley

Kondalkar, V.G. Organisational Behaviour, New Age Pub.

Roa, V.S.P. Organisational Behaviour, Excel Books

Sekaran, U. Organisational Behaviour, TMH 